OPEN ACCESS

Edited by:

Philippe Saas,

INSERM U1098 Interactions

Hôte-Greffon-Tumeur \& Ingénierie

Cellulaire et Génique, France

Reviewed by:

Andreas Hutloff,

Deutsches

Rheuma-Forschungszentrum

(DRFZ), Germany

Rosanne Spolski,

National Institutes of Health $(\mathrm{NIH})$,

United States

Troy Randall,

University of Rochester, United States

*Correspondence:

Pengcheng Zhou

pengcheng.zhou@anu.edu.au

Fang Gong

gongfang2004@163.com

tThese authors have contributed equally to this work

Specialty section:

This article was submitted to

$T$ Cell Biology,

a section of the journal

Frontiers in Immunology

Received: 22 October 2019 Accepted: 27 November 2019

Published: 13 December 2019

Citation:

Gong F, Zheng T and Zhou P (2019) T Follicular Helper Cell Subsets and the

Associated Cytokine IL-21 in the Pathogenesis and Therapy of Asthma.

Front. Immunol. 10:2918.

doi: 10.3389/fimmu.2019.02918

\section{T Follicular Helper Cell Subsets and the Associated Cytokine IL-21 in the Pathogenesis and Therapy of Asthma}

\author{
Fang Gong ${ }^{1 * t}$, Ting Zheng ${ }^{2,3 t}$ and Pengcheng Zhou ${ }^{2 * \dagger}$ \\ ${ }^{1}$ Department of Laboratory Medicine, Affiliated Hospital of Jiangnan University, Wuxi, China, ${ }^{2}$ Department of Immunology \\ and Infectious Disease, The John Curtin School of Medical Research, The Australian National University, Canberra, ACT, \\ Australia, ${ }^{3}$ Laboratory of Immunology for Environment and Health, Shandong Analysis and Test Center, Qilu University of \\ Technology (Shandong Academy of Sciences), Jinan, China
}

For many decades, Thelper $2\left(T_{H} 2\right)$ cells have been considered to predominantly regulate the pathogenic manifestations of allergic asthma, such as IgE-mediated sensitization, airway hyperresponsiveness, and eosinophil infiltration. However, recent discoveries have significantly shifted our understanding of asthma from a simple $\mathrm{T}_{\mathrm{H}} 2$ cell-dependent disease to a heterogeneous disease regulated by multiple $T$ cell subsets, including $T$ follicular helper $\left(T_{F H}\right)$ cells. $T_{F H}$ cells, which are a specialized cell population that provides help to B cells, have attracted intensive attention in the past decade because of their crucial role in regulating antibody response in a broad range of diseases. In particular, $\mathrm{T}_{\mathrm{FH}}$ cells are essential for lgE antibody class-switching. In this review, we summarize the recent progress regarding the role of $\mathrm{T}_{\mathrm{FH}}$ cells and their signature cytokine interleukin (IL)-21 in asthma from mouse studies and clinical reports. We further discuss future therapeutic strategies to treat asthma by targeting $T_{F H}$ cells and IL-21.

Keywords: $T$ follicular helper $\left(T_{F H}\right)$ cell, interleukin-21 (IL-21), $T$ follicular regulatory ( $\left.T_{F R}\right)$ cell, asthma, immunotherapy

\section{INTRODUCTION}

Asthma, one of the most common chronic and non-infectious diseases, affects around 334 million people worldwide (1). Although the mortality rate associated with asthma has declined remarkably with the regular use of inhaled corticosteroids or oral systemic corticosteroids $(2,3)$, the overall effectiveness of this therapeutic approach has remained debatable, since $5-25 \%$ of asthmatic patients are refractory and show resistance to current corticosteroid-based treatments (4). Concurrently, side effects such as poor immune response to infection and increased risk of osteoporosis are associated with long-term corticosteroid treatment in patients with asthma $(5,6)$. Therefore, novel treatments that can replace the current steroid-based therapies in a larger cohort of asthma patients and reduce the risk of side effects are urgently needed to not only improve patient outcomes but also reduce the economic burden associated with the management of severe asthma.

Because of their myriad effects on inflammatory responses in the respiratory tract, $\mathrm{CD} 4^{+} \mathrm{T}$ cells have been identified as potent regulators of asthma pathogenesis (7). In this regard, T helper $2\left(\mathrm{~T}_{\mathrm{H}} 2\right)$ cells have gradually gained recognition in studies on asthma biology $(8,9)$. Interleukin (IL)-4, IL-5, and IL-13, which are canonical type 2 cytokines produced by $\mathrm{T}_{\mathrm{H}} 2$ cells, prominently mediate the development of asthma and airway inflammation, manifesting as enhanced IgE-mediated sensitization, airway hyperreactivity (AHR), as well as eosinophil infiltration $(1,10)$. 
However, emerging evidence suggests that $\mathrm{T}$ follicular helper $\left(\mathrm{T}_{\mathrm{FH}}\right)$ cells, rather than $\mathrm{T}_{\mathrm{H}} 2$ cells, predominantly produce IL4 and IL-21 in B cell follicles and closely regulate IgE classswitching during severe asthma development in both mice and humans (11-15). Therefore, a thorough understanding of $\mathrm{T}_{\mathrm{FH}}$ cells and their signature cytokine IL-21 is important to fully elucidate the pathogenesis of asthma. In this review, we have summarized recent discoveries related to the role of $\mathrm{T}_{\mathrm{FH}}$ cells and IL-21 in mouse models and patients with asthma. In addition, we have discussed the therapeutic strategies for asthma that are based on modulation of $\mathrm{T}_{\mathrm{FH}}$ cells and IL-21, which may potentially be translated into clinical use in the near future.

\section{BIOLOGY OF $\mathrm{T}_{\mathrm{FH}}$ CELLS}

\section{Generation and Development of $\mathrm{T}_{\mathrm{FH}}$ Cells}

$\mathrm{T}$ cell and $\mathrm{B}$ cell interactions, particularly the help provided by $\mathrm{T}$ cells to B cells, have been demonstrated for decades (16-19). However, the cellular processes underlying this "help" provided to B cell follicles were not fully understood until a specialized CXCR5-expressing CD4 ${ }^{+} \mathrm{T}$ cell population, which is uniquely regulated by Bcl-6, was identified (20-22). These cells, termed as $\mathrm{T}_{\mathrm{FH}}$ cells, can access $\mathrm{B}$ cell follicles and regulate the germinal center response (23). Over the past decade, significant progress has been achieved in studying $\mathrm{T}_{\mathrm{FH}}$ cells. These "help"-providing $\mathrm{T}$ follicular cells have been revealed to markedly express inducible co-stimulator molecules (ICOS), programmed cell death 1 (PD1 ), and CD40-ligand (CD40L), which are essential for interacting with $\mathrm{B}$ cells (24). Moreover, $\mathrm{T}_{\mathrm{FH}}$ cells produce high amounts of the cytokine IL-21 in the B cell follicles $(25,26)$.

These molecules are not only determinative of the commitment of $\mathrm{T}_{\mathrm{FH}}$ cells but are also pivotal for the migration and full functionality of these cells in follicles. After activation by dendritic cells in $\mathrm{T}$ cell zone, primed $\mathrm{T}$ cells become precursor $\mathrm{T}_{\mathrm{FH}}\left(\right.$ pre- $\mathrm{T}_{\mathrm{FH}}$ ) cells and downregulate CCR7 and PSGL1 while upregulate CXCR5 for their migration into B cell follicles, where CXCL13, the ligand for CXCR5 is plentifully accumulated $(24,27)$ (Figure 1). Additionally, EBI2 and PD-1 are critical for the positioning of pre- $\mathrm{T}_{\mathrm{FH}}$ cells near the T-B border $(28,29)$. With sustained ICOS stimulation by B cells as well as downregulation of the adhesion molecules EBI2 and S1PR1, $\mathrm{T}_{\mathrm{FH}}$ cells are allowed to further develop into $\mathrm{B}$ cell follicles and
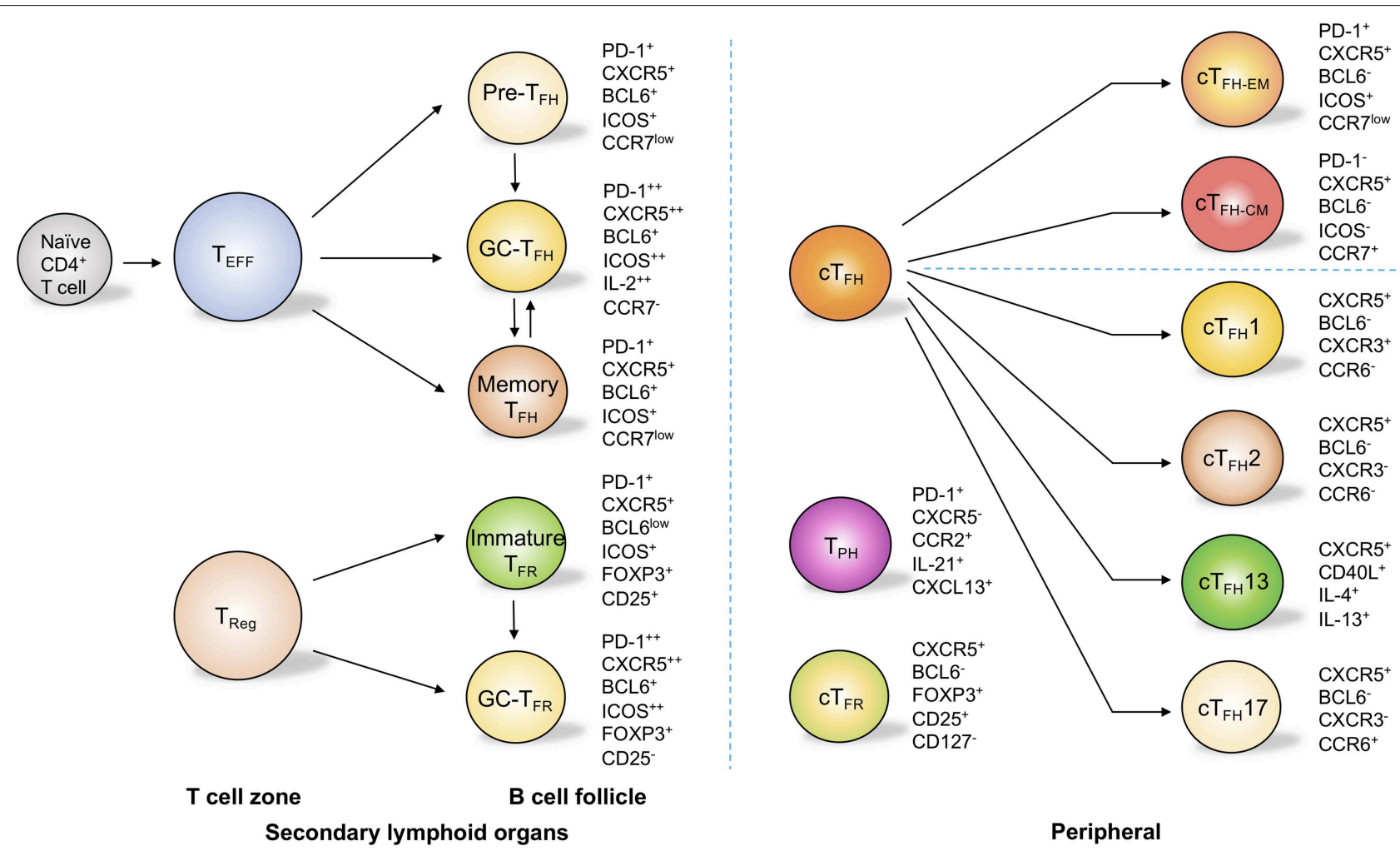

FIGURE 1 | $T_{F H}$ cell and related subsets in secondary lymph organs and in peripheral circulation. In secondary lymphoid organs, $T$ follicular helper ( $T_{F H}$ ) cells are composed of subsets with distinct phenotypes. These subsets include pre- $T_{F H}$ cells, germinal center (GC) $T_{F H}$ cells, and memory $T_{F H}$ cells. Through the upregulation of programmed cell death protein 1 (PD-1) and CXC-chemokine receptor 5 (CXCR5), regulatory $T$ ( $T_{\text {reg }}$ ) cells migrate into B cell follicles and become immature $T$ follicular regulatory $\left(T_{F R}\right)$ cells and germinal center $T_{F R}$ cells. In the peripheral circulation, circulating $T_{F H}\left(c T_{F H}\right)$ cells can be categorized into effector memory (c $\left.T_{F H-E M}\right)$ cells and central memory ( $\mathrm{CT}_{\mathrm{FH}} \mathrm{CM}$ ) cells on the basis of the expression of PD-1 and CC-chemokine receptor 7 (CCR7). $\mathrm{CT}_{\mathrm{FH}}$ cells can also be sub-grouped into $\mathrm{CT}_{\mathrm{FH}} 1, \mathrm{CT}_{\mathrm{FH}} 2, \mathrm{CT}_{\mathrm{FH}} 13$, and $\mathrm{CT}_{\mathrm{FH}} 17$ cells on the basis of the differential expression of $\mathrm{CXCR} 3$ and CCR6 as well as the secretion of interleukin-4 (IL-4) and IL-13. Circulating $T_{F R}$ cells are similar to $T_{\text {reg }}$ cells but express CXCR5. Notably, T peripheral helper ( $\left.T_{\mathrm{PH}}\right)$ cells do not express CXCR5 but can produce IL-21 and CXCL13, which allows them to provide help to B cells. 
are retained in the germinal centers to become germinal center $\mathrm{T}_{\mathrm{FH}}\left(\mathrm{GC}-\mathrm{T}_{\mathrm{FH}}\right)$ cells $(23,30,31)$ (Figure 1). Bcl-6 is essential for this complex cellular process, since it promotes CXCR5 expression while repressing the expression of the transcription factors T-bet, GATA-3, and ROR $\gamma$ t, molecules that are essential for the induction of other subsets of effector CD4 ${ }^{+} \mathrm{T}$ cells such as $\mathrm{T}_{\mathrm{H}} 1, \mathrm{~T}_{\mathrm{H}} 2$, and $\mathrm{T}_{\mathrm{H}} 17$ cells $(32,33)$. Moreover, Bcl-6 inhibits CCR6, PSGL1, CCR7, and S1PR1, the cell surface molecules that regulate non-follicular localization of effector $\mathrm{CD} 4^{+} \mathrm{T}$ cells (23). Antagonistically, the transcriptional repressor B lymphocyteinduced maturation protein 1 (Blimp-1) negatively acts on Bcl-6 to inhibit $\mathrm{T}_{\mathrm{FH}}$ development. Transcription factors such as c-Maf, FOXO1, Id3, TCF-1, IRF4, and ASCL2 are also known to play important roles in fine-tuning the sophisticated cellular regulatory network during $\mathrm{T}_{\mathrm{FH}}$ development and function (23).

\section{Cytokine Milieu Regulates $\mathrm{T}_{\mathrm{FH}}$ Cell Development and Differentiation}

Development of $\mathrm{T}_{\mathrm{FH}}$ cells is also dependent on the cytokine milieu. Mouse studies have revealed that IL-6, IL-12, and IL27 induce the expression of Bcl-6 and promote $\mathrm{T}_{\mathrm{FH}}$ lineage differentiation through the activation of the transcription factors STAT3 and/or STAT4 (34-38). In humans, TGF- $\beta$ together with IL-12 and IL-23 may contribute to the generation of human $\mathrm{T}_{\mathrm{FH}}$ cells (39). In contrast, the TGF- $\beta$ signal exerts suppressive effects in regulating the production of IL-21 and expression of ICOS and Bcl-6 in mouse $\mathrm{T}_{\mathrm{FH}}$ cells (39). Nevertheless, IL-2 is a suppressive molecule that inhibits the generation of both human and mouse $\mathrm{T}_{\mathrm{FH}}$ cells in a STAT5- and Blimp1-dependent manner $(40,41)$.

\section{Circulating $T_{F H}$ Cells and Subsets of $T_{F H}$ Cells}

Although $\mathrm{T}_{\mathrm{FH}}$ cells possesses distinctive characteristics in comparison with other subsets of $\mathrm{CD}^{+} \mathrm{T}$ cells, they can produce $\mathrm{T}_{\mathrm{H}} 1, \mathrm{~T}_{\mathrm{H}} 2$, and $\mathrm{T}_{\mathrm{H}} 17$-type cytokines. Indeed, Reinhardt et al. (42), Zaretsky and Hirota etc. have shown that $\mathrm{T}_{\mathrm{FH}}$ cells, especially circulating or tissue-resident $\mathrm{T}_{\mathrm{FH}}$ cells, produce IL- 4 or IL-17 to modulate antibody responses $(43,44)$. Bona fide germinal center $\mathrm{T}_{\mathrm{FH}}$ cells can also produce IL- 4 , IFN- $\gamma$, or IL-17 to regulate antibody outcomes (42-44).

After the contraction phase of the immune response, a small proportion of $\mathrm{CD}^{+}{ }^{+} \mathrm{T}$ cells give rise to memory $\mathrm{T}$ cells, which confer long-lasting immunity to the host to defend it against recurrent invasions of pathogens. Indeed, MacLeod et al. (45) have shown that $\mathrm{CXCR}^{+}$memory $\mathrm{CD} 4^{+} \mathrm{T}$ (memory $\mathrm{T}_{\mathrm{FH}}$ ) cells (Figure 1) accelerate the generation of functional $\mathrm{T}_{\mathrm{FH}}$ cells and promote OVA-specific IgG1 titers in OVA immunization. Moreover, influenza vaccination promotes the levels of circulating $\mathrm{T}_{\mathrm{FH}}$ cells $\left(\mathrm{cT}_{\mathrm{FH}}\right)$ cells in human blood, and these $\mathrm{cT}_{\mathrm{FH}}$ cells correlate with a boosting of antigen-specific $\mathrm{B}$ cell response (46). These data strongly suggest that memory $\mathrm{T}_{\mathrm{FH}}$ cells exist in circulating blood and that these cells can foster rapid and high-quality antibody response.

Interestingly, memory $\mathrm{T}_{\mathrm{FH}}$ cells in circulation are not only able to promote recall response, but are with plasticity to give rise to other functional effector T cells in different contexts $(47,48)$.
It is also noticed in germinal center that $\mathrm{GC}-\mathrm{T}_{\mathrm{FH}}$ cells switch to produce IL-4 from IL-21 as the germinal center reaction evolved (49). These evidences suggest that $\mathrm{T}_{\mathrm{FH}}$ cells are not terminally differentiated cells and maintain flexibility to convert into other functional $\mathrm{CD}^{+}{ }^{+} \mathrm{T}$ cell subsets.

On the basis of the differential expressions of the chemokine receptors CXCR3 and CCR6, peripheral circulating $\mathrm{T}_{\mathrm{FH}}\left(\mathrm{cT}_{\mathrm{FH}}\right)$ cells can be divided into three major subsets: $\mathrm{cT}_{\mathrm{FH}} 1$ cells $\left(\mathrm{BCL}^{-} \mathrm{CXCR}^{+} \mathrm{CCR}^{-}\right)$, $\mathrm{cT}_{\mathrm{FH}} 2$ cells $\left(\mathrm{BCL}^{-} \mathrm{CXCR}^{-} \mathrm{CCR}^{-}\right)$, and $\mathrm{cT}_{\mathrm{FH}} 17$ $\left(\mathrm{BCL6}^{-} \mathrm{CXCR}^{-} \mathrm{CCR}^{+}\right.$) cells (50) (Figure 1). These subsets are transcriptionally different and produce distinct cytokines to regulate humoral response (50). Of note, $\mathrm{cT}_{\mathrm{FH}} 2$ and $\mathrm{cT}_{\mathrm{FH}} 17$ cells, but not the $\mathrm{cT}_{\mathrm{FH}} 1$ population, are characterized as efficient helper $\mathrm{T}_{\mathrm{FH}}$ cells to promote the class-switching of immunoglobulin (50). $\mathrm{cT}_{\mathrm{FH}} 2$ cells promote IgG and IgE secretion, whereas blood $\mathrm{cT}_{\mathrm{FH}} 17$ cells induce IgG and IgA secretion (50). Interestingly, a group of peripheral $\mathrm{T}$ cells defined as $\mathrm{T}$ peripheral helper cells $\left(\mathrm{T}_{\mathrm{PH}}\right)$ do not express CXCR5 but can produce IL-21 and CXCL13 (Figure 1), which allows them to provide help to B cells $(51,52)$. Meanwhile, a group of CD4 ${ }^{+} \mathrm{T}$ cells expressing CXCR3 and PD-1 but not CXCR5 have been found in both blood and tubulointerstitial areas in lupus patients (53). These cells provide the help to B cells through the production of IL-10 and succinate instead of IL-21 (53). It is with interest to know in the future how these non-classic "B cell help" $\mathrm{CD} 4{ }^{+} \mathrm{T}$ cells correlate with each other and with classic $\mathrm{T}_{\mathrm{FH}}$ cells. Notably, classic human circulating $\mathrm{T}_{\mathrm{FH}}$ cells can also be categorized into distinct effector stages by evaluating the expression levels of ICOS, PD-1, and CCR7 $(54,55)$. On the basis of this strategy, activated-stage (effector memory) $\mathrm{cT}_{\mathrm{FH}}\left(\mathrm{cT}_{\mathrm{FH}}-\mathrm{EM}\right)$ cells are defined as $\mathrm{PD}$ $1^{+} \mathrm{CXCR}^{+} \mathrm{BCL}^{-} \mathrm{ICOS}^{+} \mathrm{CCR}^{\text {low }}$ cells, which are similar to pre- $\mathrm{T}_{\mathrm{FH}}$ cells, while $\mathrm{PD}-1^{-} \mathrm{CXCR}^{+} \mathrm{BCL}^{-}{ }^{-} \mathrm{ICOS}^{-} \mathrm{CCR}^{+}$cells are characterized as central memory $\mathrm{cT}_{\mathrm{FH}}$ cells $\left(\mathrm{cT}_{\mathrm{FH}-\mathrm{CM}}\right)$ and can persist for weeks after antigen stimulation $(54,55)$ (Figure 1). Interestingly, within blood $\mathrm{cT}_{\mathrm{FH}} 1$ cells, the helper ability is restricted mostly to the activated $\mathrm{ICOS}^{+} \mathrm{PD}-1^{+} \mathrm{CCR}^{\text {low }}$ subset, while within $\mathrm{cT}_{\mathrm{FH}} 2$ and $\mathrm{cT}_{\mathrm{FH}} 17$ cells, both activated and central memory subsets are capable of providing help signals to the $\mathrm{B}$ cells $(56,57)$. In fact, the activated $\mathrm{ICOS}^{+} \mathrm{PD}-1^{+} \mathrm{CCR} 7$ low subset represents the most efficient helper cells among $\mathrm{CT}_{\mathrm{FH}}$ cells $(56,57)$. Beyond this classification, a study using a murine model with dedicator of cytokinesis 8 (Dock8) deficiency revealed a subset of IL-13-producing $\mathrm{T}_{\mathrm{FH}}$ cells associated with high-affinity IgE production (58) (Figure 1). These “ $\mathrm{T}_{\mathrm{FH}} 13$ " cells, which are present in both mice and humans, have a unique cytokine profile (IL-13 ${ }^{+} \mathrm{IL}-4^{+}$) and co-express Bcl-6 and GATA-3 (58). These cells were further demonstrated to be responsible for the production of high-affinity anaphylactic IgE but not low-affinity $\operatorname{IgE}(58)$.

\section{ROLE OF $T_{F H}$ CELLS IN ASTHMA PATHOGENESIS}

Since $\mathrm{T}_{\mathrm{FH}}$ cells are indispensable for antibody maturation, investigators have studied the role of these cells in many disease 
contexts, including asthma (23). Emerging evidence from both mouse and human studies has elucidated that subsets of $\mathrm{T}_{\mathrm{FH}}$ cells differentially contribute to the development of asthma (Table 1). These observations have broadened our understanding of asthma and provided novel options to treat asthma by targeting $\mathrm{T}_{\mathrm{FH}}$ cells from different angles.

\section{$\mathrm{T}_{\mathrm{FH}}$ Cells in Murine Asthma Models}

Like in the case of other immune diseases, animal models serve as a feasible approach to investigate the pathogenesis of asthma. To fully understand how $\mathrm{T}_{\mathrm{FH}}$ cells participate in asthma development, multiple allergens such as house dust mite (HDM), ovalbumin (OVA), molds, and cockroach antigens have been utilized to induce asthma symptoms in mice (74).

Using an HDM-induced asthma mouse model, BallesterosTato et al. (11) showed that the initial intranasal sensitization with HDM directly induces IL-4-producing $\mathrm{T}_{\mathrm{FH}}$ cells, and these cells then become IL- $4^{+} \mathrm{IL}-13^{+} \mathrm{T}_{\mathrm{H}} 2$ cells after the HDM challenge. Interestingly, depletion of $\mathrm{T}_{\mathrm{FH}}$ cells after HDM sensitization successfully prevents $\mathrm{T}_{\mathrm{H}} 2$ cell-mediated immunity after secondary exposure (11). These results are supported by recent studies showing that $\mathrm{T}_{\mathrm{FH}}$ cells can further differentiate into functional subsets to regulate antibody response (11, 47, 75, 76). Meanwhile, studies have also shown that the airborne allergen HDM independently induces $\mathrm{T}_{\mathrm{H}} 2$ or
$\mathrm{T}_{\mathrm{FH}}$ cells to regulate eosinophilic airway inflammation and IgE production, which raises more questions related to the clear definition of the different roles of $\mathrm{T}_{\mathrm{H}} 2$ and $\mathrm{T}_{\mathrm{FH}}$ cells in HDM-induced asthma $(12,13)$. More importantly, these studies have revealed a rare but important IL-21 producing $\mathrm{CD}^{+} \mathrm{T}$ cells that are highly pathogenic and can synergize airway inflammation in the lung tissue $(12,60)$. These cells are different from classical $\mathrm{T}_{\mathrm{FH}}$ cells as they lack expression of Bcl-6 and CXCR5 and don't require ICOS signaling (12, $60,61)$. In another peanut-induced asthma mouse model, $\mathrm{T}_{\mathrm{FH}}$ cells robustly promoted peanut-specific IgE production (59). In this model, depletion of $\mathrm{T}_{\mathrm{FH}}$ cells decreased IgE production and protected mice from anaphylaxis without affecting $\mathrm{T}_{\mathrm{H}} 2$ cells (59). Thus, $\mathrm{T}_{\mathrm{FH}}$ cells are necessary and sufficient for the $\mathrm{B}$ cell class-switching and sustained IgE production in the absence of $\mathrm{T}_{\mathrm{H}} 2$ cells $(13,59)$. In line with this result, mice with $\mathrm{T}$ cell specific IL-6R deficiency exhibit limited $\mathrm{T}_{\mathrm{FH}}$ expansion after HDM sensitization and significantly impaired IgE response (14). Moreover, a rare population defined as IL-13 producing $\mathrm{T}_{\mathrm{FH}}\left(\mathrm{T}_{\mathrm{FH}} 13\right)$ cells is reported to be essential for the production of high-affinity IgE antibody and the subsequent allergen-induced anaphylaxis (58). Eliminating $\mathrm{T}_{\mathrm{FH}} 13$ cells or $\mathrm{T}_{\mathrm{FH}}$ cell-derived IL-13 during allergen immunization results in the abrogation of high-affinity anaphylactic IgE (58).

TABLE 1 | T follicular cells in mouse/human asthma and related allergic diseases.

\begin{tabular}{|c|c|c|c|c|c|}
\hline Species & Model/Patients & Location & Dysfunction & Effect & References \\
\hline \multirow[t]{8}{*}{ Mouse } & Peanut & $\mathrm{mLN}$ & $\mathrm{T}_{\mathrm{FH} 1 \uparrow}$ & $\mathrm{T}_{\mathrm{FH}}$ cells promote peanut-specific lgE production. & (59) \\
\hline & HDM & $\mathrm{mLN}$ & $\mathrm{T}_{\mathrm{FH}} 2 \uparrow$ & $\mathrm{T}_{\mathrm{FH}}$ cells are precursors of HDM-specific $\mathrm{T}_{\mathrm{H}} 2$ cells. & $(11)$ \\
\hline & HDM & $\mathrm{mLN}$ & $\mathrm{T}_{\mathrm{FH}} 2 \uparrow$ & $\begin{array}{l}T_{F H} \text { cells amplify } T_{H} 2 \text { cell function in allergic airway inflammation; } \\
T_{F H} \text { cells support the sustained production of IgE antibody in vivo. }\end{array}$ & $(12-14)$ \\
\hline & HDM & Lung & $\mathrm{CD} 4^{+} \mathrm{IL}-21^{+} \uparrow$ & Promotes local inflammation in the airway & $(12,60,61)$ \\
\hline & HDM and Peanut & $\mathrm{mLN}$ & $\mathrm{T}_{\mathrm{FH}} 13 \uparrow$ & $\begin{array}{l}T_{F H} \text { cells are required for production of high-affinity, but not } \\
\text { low-affinity, IgE and subsequent allergen-induced anaphylaxis. }\end{array}$ & $(58)$ \\
\hline & HDM & $\mathrm{mLN}$ & $\mathrm{T}_{\mathrm{FH}} 13 \uparrow, \mathrm{T}_{\mathrm{FR}} \downarrow$ & $\mathrm{T}_{\mathrm{FR}}$ cells can limit $\mathrm{T}_{\mathrm{FH}} 13$ cell-promoted lgE production. & $(62)$ \\
\hline & $\begin{array}{l}\text { Transplantation (not } \\
\text { clear in Asthma) }\end{array}$ & mLN, Spleen & $\mathrm{T}_{\mathrm{FH}} 17 \uparrow, \mathrm{T}_{\mathrm{FR}} \downarrow$ & $\begin{array}{l}\text { IL-10-producing marginal zone precursor } \mathrm{B} \text { cells control the } \\
\text { differentiation of } \mathrm{T}_{\mathrm{FH}} \text { cells and are necessary for immune tolerance. }\end{array}$ & (63) \\
\hline & OVA Immunization & mLN, Spleen & $T_{F R} \downarrow$ & $\begin{array}{l}\text { Deficiency of } T_{F R} \text { cells leads to excessive humoral immune } \\
\text { responses. }\end{array}$ & $(64,65)$ \\
\hline \multirow[t]{8}{*}{ Human } & $\begin{array}{l}\text { Juvenile } \\
\text { Dermatomyositis (not } \\
\text { clear in Asthma) }\end{array}$ & Blood & $\begin{array}{l}\mathrm{CT}_{\mathrm{FH}} 1 \downarrow, \mathrm{CT}_{\mathrm{FH}} 2 \uparrow \\
\mathrm{CT} \mathrm{T}_{\mathrm{FH} 17 \uparrow}\end{array}$ & $\begin{array}{l}\mathrm{CT}_{\mathrm{FH}} 2 \text { and } \mathrm{CT}_{\mathrm{FH}} 17 \text { cells, but not } \mathrm{CT}_{\mathrm{FH}} 1 \text { population, are } \\
\text { characterized as efficient helper } \mathrm{T}_{\mathrm{FH}} \text { cells to promote the } \\
\text { class-switching of immunoglobulins. }\end{array}$ & $(50)$ \\
\hline & Allergic Asthma & Blood & $\mathrm{CT}_{\mathrm{FH}} 2 \uparrow$ & $\mathrm{T}_{\mathrm{FH}}$ cells positively correlate with the total lgE level. & $(66-68)$ \\
\hline & Peanut-Allergen & Blood & $\mathrm{CT}_{\mathrm{FH}} 13 \uparrow$ & / & $(58)$ \\
\hline & HDM-Allergen & Blood & $\mathrm{CT}_{\mathrm{FH}} \uparrow, \mathrm{CT} \mathrm{T}_{\mathrm{FR}} \downarrow$ & AIT efficiently modulates the balance of circulating $T_{F H}$ and $T_{F R}$. & (69) \\
\hline & Allergic Rhinitis & Blood & $\mathrm{CT}$ FR $\downarrow$ & AIT efficiently reinvigorates $T_{F R}$ cells to control IgE production. & $(70)$ \\
\hline & Asthma & Blood & $\mathrm{CT}$ FR $\downarrow$ & $\begin{array}{l}T_{F R} \text { cells produce high amounts of } I L-10 \text {, which may inhibit the } \\
\text { generation of pathogenic } T_{F H} \text { cells. }\end{array}$ & $(71-73)$ \\
\hline & $\begin{array}{l}\text { Rheumatoid Arthritis } \\
\text { (not clear in Asthma) }\end{array}$ & Blood & $\mathrm{T}_{\mathrm{PH} \uparrow} \uparrow$ & $\mathrm{T}_{\mathrm{PH}}$ cells promote $\mathrm{B}$ cell responses and antibody production. & (51) \\
\hline & $\begin{array}{l}\text { Lupus (not clear in } \\
\text { Asthma) }\end{array}$ & Blood & $\mathrm{T}_{\mathrm{PH}} \uparrow$ & TPH cells stimulate B cell responses via IL-21. & (52) \\
\hline
\end{tabular}

HDM, house dust mite; $m L N$, mediastinal lymph node; AlT, allergen-specific immunotherapy. 


\section{$\mathbf{T}_{\mathrm{FH}}$ Cells in Human Asthma}

In human studies, our group and other groups have found significantly higher circulating $\mathrm{T}_{\mathrm{FH}}$ cell $\left(\mathrm{CXCR} 5^{+} \mathrm{CD} 4^{+}\right)$levels in both child and adult asthma patients in comparison with healthy cohorts $(66,67)$. Additionally, a skewed peripheral $\mathrm{T}_{\mathrm{FH}}$ cell phenotype toward the $\mathrm{T}_{\mathrm{FH}} 2$ phenotype has been identified in asthma patients, where the frequency of $\mathrm{T}_{\mathrm{FH}} 2$ cells positively correlated with total IgE levels in the blood (66). We have further observed that circulating $\mathrm{T}_{\mathrm{FH}}$ cells enhance IgE production, which can be reduced by blocking IL-4 or IL-21 (77). Moreover, the levels of IL- ${ }^{+}$IL- $21^{+} \mathrm{CXCR}^{+} \mathrm{CD} 4{ }^{+} \mathrm{T}$ cells have been shown to positively correlate with the total $\operatorname{IgE}$ level in vivo (77). These results indicate that circulating CXCR5 ${ }^{+} \mathrm{CD} 4^{+} \mathrm{T}_{\mathrm{FH}}$ cells support the germinal center production of $\mathrm{IgE}$ in asthma patients. Interestingly, studies using microRNA have revealed that miR192 is a promising therapeutic target in asthma patients as it inhibits $\mathrm{T}_{\mathrm{FH}}$ cell differentiation $(67,78)$. Of note, allergen-specific immunotherapy (AIT), which leads to improved prognosis in allergic patients, efficiently reduces circulating $\mathrm{T}_{\mathrm{FH}}$ cell levels $(68,69)$. AIT treatment also markedly increases the frequency of $\mathrm{T}$ follicular regulatory $\left(\mathrm{T}_{\mathrm{FR}}\right)$ cells, which are known to suppress the germinal center reaction $(69,70)$.

\section{BIOLOGY OF IL-21}

IL-21 and IL-21R were discovered in 2000 (79, 80). As a pleiotropic type I four- $\alpha$-helical bundle cytokine, IL-21 is predominantly produced by NKT cells and activated $\mathrm{CD} 4^{+} \mathrm{T}$ cells such as $\mathrm{T}_{\mathrm{H}} 9$ cells, $\mathrm{T}_{\mathrm{H}} 17$ cells, and $\mathrm{T}_{\mathrm{FH}}$ cells $(81,82)$. IL21 exerts its biological function via binding to its heterodimeric receptor. This receptor is composed of the common $\gamma$-chain subunit shared with IL-2 family cytokines, including IL-4, IL-7, IL-9, and IL-15, and its own unique receptor (designated IL21R), a member of the class I cytokine receptor family (83). Although the production of IL-21 is restricted to lymphocytes, IL-21R is universally expressed on a large range of immune and non-immune cells, indicating its broad physiological effects $(79,80)$. Recent advances have revealed that IL-21 promotes the activation and cytotoxic function of NK and NKT cells $(84,85)$. IL-21 also enhances the anti-viral and tumor function of $\mathrm{CD}^{+}$ $\mathrm{T}$ cells $(82,86,87)$. In particular, IL-21 regulates the formation and function of $\mathrm{CD} 4^{+} \mathrm{T}$ cell subsets, including the promotion of IL-17-producing T cells $\left(\mathrm{T}_{\mathrm{H}} 17\right)(88,89)$, efficient development of $\mathrm{T}_{\mathrm{FH}}$ cells (90), and limitation of $\mathrm{T}_{\mathrm{FR}}$ cells (64). IL-21 is essential for $\mathrm{B}$ cell differentiation and activation. In this context, IL-21 induces $B$ cell proliferation and differentiation to either memory $B$ cells or terminally differentiated plasma cells egressing from the germinal center $(82,91)$. In addition, IL-21 plays fundamental roles in regulating Ig class-switching and maintaining germinal center reaction $(82,92,93)$.

As a potent cellular modulator, IL-21 binds to the IL-21R and stabilizes the IL-21R- $\gamma_{c}$ (common cytokine receptor $\gamma$ chain) complex, which leads to the activation of downstream signaling cascades (94). Which signaling pathways are particularly important to regulate the formation, function, and fate of $\mathrm{T}$ and $\mathrm{B}$ cells? Janus kinase 1 (JAK1) and JAK3 have been shown to be largely activated by the IL-21R- $\gamma_{c}$ complex. This activation leads to strong phosphorylation of signal transducer and activator of transcription protein 3 (STAT3), which will further dimerize and translocate into the nucleus for target genes (94). In $\mathrm{T}$ cells, activated STAT3 signaling results in increased expression of retinoic acid receptor-related orphan receptor- $\gamma \mathrm{t}(R O R C)$ and enhanced production of IL-17 and IL-21 (88, 89, 95, 96). This IL-21-STAT3 axis can also directly promote IL-6 mediated Bcl6 expression, which induces the upregulation of CXCR5, ICOS, and PD-1 during $\mathrm{T}_{\mathrm{FH}}$ cell development $(23,25,97)$ (Figure 2). Although future studies are required to determine whether IL-21 is superior to other STAT3 inducing cytokines such as IL-6 on the regulation of $\mathrm{T}_{\mathrm{FH}}$ cells in vivo (98), IL-21 is at least partially required for the potentiation of $\mathrm{T}_{\mathrm{FH}}$-like cells in vitro $(90,99)$. Additionally, IL-21 also regulates the target genes in $\mathrm{T}$ cells through BATF, JUN, and IRF4 (100). In B cells, IL-21 maintains Bcl-6 expression in germinal center B cells $(101,102)$ while it increases the expression of Blimp1 ( Prdm1), which promotes plasma cell differentiation (91). IL-21 also regulates the apoptosis of $\mathrm{B}$ cells through the modulation of BIM (Bcl-2 interacting mediator of cell death) $(103,104)$ (Figure 2).

These IL-21-initiated pivotal signaling pathways can be targeted through agonists or antagonists (inhibitors) to modulate $\mathrm{T}$ and $\mathrm{B}$ cell development and function, and more importantly, intervene and treat multiple immune related diseases, including asthma.

\section{ROLE OF IL-21 IN ASTHMA PATHOGENESIS}

\section{IL-21 in the Pathogenesis of Murine Asthma}

The IL-21 transcript is upregulated in the lung and lungdraining lymph nodes during allergic airway response $(12,105)$. The protein levels of IL-21 and IL-21R are also increased in the pulmonary tissues of asthmatic rats (106). Additionally, IL-21 level is elevated in the serum and bronchoalveolar lavage fluid (BALF) of asthmatic mice $(107,108)$.

IL-21 has anti-IgE and anti-inflammatory effects (93, 109113). Indeed, Il21r-deficient mice exhibit high levels of IgE, and IL-21 inhibits IL-4-induced IgE secretion by B cells $(105,114)$. In the OVA-induced asthma model, the administration of exogenous IL-21 reduced IgE production and decreased eosinophil recruitment into the airway (109). Consistent with this data, Lin et al. have confirmed in vivo that intranasal administration of IL-21-expressing adenovirus suppresses allergic responses (115). Additionally, in this model, administration of IL-21 not only reduces the frequency of $\mathrm{T}_{\mathrm{H}} 2$ cells but suppresses the secretion of $\mathrm{T}_{\mathrm{H}} 2$-associated cytokines such as IL-4, IL-5, and IL-13 (115). In line with this observation, $\mathrm{Wu}$ et al. have shown that nasal administration of rmIL-21 significantly reduced the AHR, inflammatory cell infiltration, IgE-producing B cell level, and total serum IgE level (116). As mentioned above, serum total and HDM-specific IgE antibody titers are markedly higher in $I l 21 r$-deficient mice (105). However, 


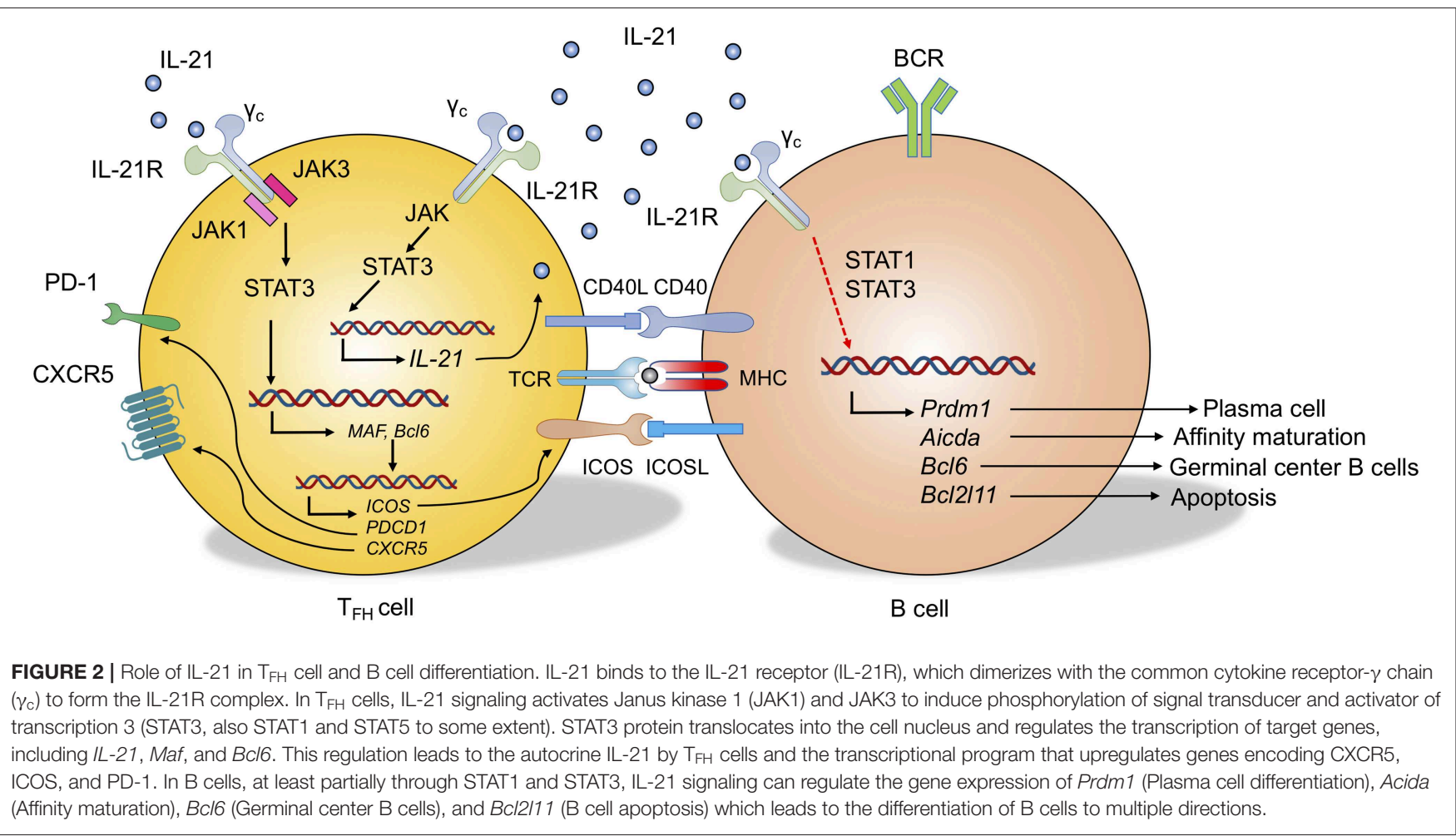

Il21r-deficient mice develop unexpectedly less AHR in an HDM model of asthma (105). Similar results showing a decline in AHR are also observed in an OVA-induced experimental asthma model using Il21r-deficient mice (114). These findings suggest that IL-21 is importantly involved in the development of asthma. While the mechanisms underlying the dichotomy in the role of IL-21 in regulating IgE and AHR remain poorly understood, they are presumably related to the location and timing of the differential accumulation of IL-21 during disease development.

\section{IL-21 in Human Asthma}

The main obstacle in studying the immunopathology of asthma in human subjects is the relative inaccessibility of inflamed tissues. Nonetheless, using bronchial biopsies, IL-21 expression has been shown to be elevated in both moderate and severely asthmatic individuals (105). Additionally, an increased IL-21 level appears to be associated with increased infiltration of inflammatory cells in the submucosa and is correlated with asthma severity (105). In addition, the plasma level of IL-21 is significantly elevated in asthma patients in comparison with healthy controls (117). Consistently, an increased frequency of IL-21-expressing $\mathrm{CD}^{+}{ }^{+} \mathrm{T}$ cells is also observed in asthma patients. This increased frequency positively correlates with total IgE levels in the blood (77). Moreover, in vitro experiments have demonstrated that blocking IL-21 in the coculture assay of $\mathrm{B}$ cells with $\mathrm{CXCR} 5^{+} \mathrm{CD} 4^{+} \mathrm{T}$ cells results in decreased IgE antibody production by $\mathrm{B}$ cells (77). Besides, Chatterjee et al. have reported that the exon-3 polymorphism C5250T of the IL-21 gene was significantly associated with atopic asthma and total IgE level (118).

\section{CLINICAL IMPLICATIONS}

The increasing number of studies on $\mathrm{T}_{\mathrm{FH}}$ cells and IL21 have inspired numerous possibilities for the development novel immunotherapies to treat asthma. As mentioned above, modulating IL-21 and $\mathrm{T}_{\mathrm{FH}}$ cell-regulated IgE production may effectively control asthma development and alleviate inflammatory and hyperresponsiveness symptoms in patients.

\section{$\mathrm{T}_{\mathrm{FH}}$ Cells and Serum IL-21 as Biomarkers in Asthma}

Precise and early diagnosis of asthma and related syndromes is critical for the prompt control of disease development in patients. Lung function tests for timely and accurate diagnosis of asthma are not as feasible in children as they are in adults. As evidenced in recent clinical studies, the frequency of $\mathrm{cT}_{\mathrm{FH}}$ cells and/or the IL-21 level in peripheral blood mononuclear cells (PBMCs) appear to be the promising diagnostic biomarkers for IgE production and asthma symptoms $(66,67,77) . \mathrm{cT}_{\mathrm{FH}}$ cells and IL-21 levels can be potentially included in future diagnostic criteria for asthma. Moreover, future portable devices equipped with a method to analyze $\mathrm{cT}_{\mathrm{FH}}$ cells and IL-21 may allow efficient and precise diagnosis of asthma in those who have a family history of the disease or are highly susceptible to severe asthma due to genetic defects and environmental factors. 


\section{Limiting Pathogenic $\mathrm{T}_{\mathrm{FH}}$ Cells in Asthma}

Many approaches can be utilized to target pathogenic $\mathrm{T}_{\mathrm{FH}}$ cells. For example, $\mathrm{T}_{\text {reg }}$ cells are known to reinstate immune tolerance and prevent exaggerated immune response through their immune-suppressive function (119). Deficiency of $\mathrm{T}_{\text {reg }}$ cells in both mice and humans leads to the excessive humoral immune responses characterized by spontaneous germinal center formation and increased frequency of pathogenic $\mathrm{T}_{\mathrm{FH}}$ cells $(65,120,121)$. Indeed, temporary depletion of $\mathrm{T}_{\text {reg }}$ cells leads to enhanced secondary immune response upon antigen rechallenge (65). This enhanced memory immune response occurs partially through the reduction of CTLA-4-directed inhibition of CD80/CD86 on B cells, which results in an increased frequency of $\mathrm{T}_{\mathrm{FH}}$ cells (65).

Furthermore, by upregulating CXCR5, a significant proportion of $\mathrm{T}_{\text {reg }}$ cells migrate into $\mathrm{B}$ cell follicles and exert suppressive functions on $\mathrm{T}_{\mathrm{FH}}$ cells and GC B cells $(122,123)$. These cells, which are termed as $\mathrm{T}_{\mathrm{FR}}$ cells, are considered to control autoimmunity and germinal center reaction (124) (Figure 1) as well as autoreactive B cell clones in infection (125). Human clinical studies have shown that allergen immunotherapy reinvigorates the $T_{\mathrm{FR}}$ cells in patients with allergic rhinitis, and the addition of human $\mathrm{T}_{\mathrm{FR}}$ cells in the $\mathrm{T}_{\mathrm{FH}}$ and $\mathrm{B}$ cell coculture system remarkably reduced $\mathrm{T}_{\mathrm{FH}}$ cell-promoted $\mathrm{IgE}$ production (70). It is thus of interest to see how $\mathrm{T}_{\mathrm{FR}}$ cells respond in asthma patients in future studies. Moreover, specialized human IL-10-producing CD25 ${ }^{+}$Foxp $3^{-} \mathrm{T}_{\mathrm{FR}}$ cells effectively control IgE production (126). In the most recent study, Clement et al. revealed that $\mathrm{T}_{\mathrm{FR}}$ cells can limit $\mathrm{T}_{\mathrm{FH}} 13$ cell-promoted IgE in mouse, and depletion of $\mathrm{T}_{\mathrm{FR}}$ cells enhances antigen-specific IgE antibody and exacerbates lung inflammation (62). These studies suggest promising paths to inhibit pathogenic $\mathrm{T}_{\mathrm{FH}}$ cells and IgE production in asthma, and also shed light on the development of novel immunotherapies in asthma patients by promoting $\mathrm{T}_{\text {reg }} / \mathrm{T}_{\mathrm{FR}}$ cell-mediated suppression of $\mathrm{T}_{\mathrm{FH}}$ cells.

Administration of cytokine and/or antibodies has been considered to be an effective method to reinstate the balance of immune response in many types of diseases including asthma (127). IL-2 has been shown to vigorously suppress $\mathrm{T}_{\mathrm{FH}}$ cells (40). Indeed, clinical studies have proven that low-dose IL-2 treatment in systemic lupus erythematosus (SLE) patients safely and effectively limits autoimmunity partially through direct inhibition of self-reactive $\mathrm{T}_{\mathrm{FH}}$ cells (41). Besides, other cytokines may also potentiate the repression of pathogenic $\mathrm{T}_{\mathrm{FH}}$ cells in asthma. For example, IL-7 is reported to repress Bcl-6 and the gene profile of $\mathrm{T}_{\mathrm{FH}}$ cells in chronic viral infection, which leads to the generation of a memory pool of effector $\mathrm{T}$ cells (128). Although lack of CXCR5 and Bcl-6 expression, a specialized IL21 producing $\mathrm{CD}^{+} \mathrm{T}$ cell population is reported to provide help to B cells and synergize airway inflammation in lung tissue $(12,60)$. The role of these cells in human asthma is still unknown, nevertheless, it is of great interest to understand these non-classic $\mathrm{T}_{\mathrm{FH}}$ cells in the future as targeting on their IL-21 production may ameliorate lung inflammation in asthma. Moreover, IL10 resolves the inflammation in asthma (71-73). Studies have shown that IL-10-producing marginal zone precursor B cells control the differentiation of $\mathrm{T}_{\mathrm{FH}}$ cells and are necessary for immune tolerance (63). $\mathrm{T}_{\text {reg }}$ cells and $\mathrm{T}_{\mathrm{FR}}$ cells produce high amounts of IL-10, which may be the underlying mechanism of the $\mathrm{T}_{\text {reg }} / \mathrm{T}_{\mathrm{FR}}$ cell-mediated inhibition of pathogenic $\mathrm{T}_{\mathrm{FH}}$ cells and allergen-specific IgE antibody production. Type I interferon counteracts with STAT3 to restrain $\mathrm{T}_{\mathrm{FH}}$ cells (129). Interestingly, type I interferon has been also shown to suppress infectioninduced asthma $(130,131)$. In particular, future studies should aim to determine whether targeting of type I interferons will eliminate pathogenic $\mathrm{T}_{\mathrm{FH}}$ cells and resolve asthma in patients. Of note, combination therapy with mixed cytokines, cytokinecells, and cytokine-chemical may provide even better suppression of pathogenic $\mathrm{T}_{\mathrm{FH}}$ cells. For example, the combination of IL-10 or IL-2 with $\mathrm{T}_{\text {reg }}$ or $\mathrm{T}_{\mathrm{FR}}$ cells may synergize the immuno-suppressive function of pathogenic $\mathrm{T}_{\mathrm{FH}}$ cells and confer improved control of asthma symptoms in patients.

\section{Modulating IL-21 Signaling in Asthma}

IL-21 and IL-21R are emerging as promising targets for novel cytokine-based immunotherapies in many diseases, including SLE, primary immunodeficiency (PID), chronic lymphocytic leukemia (CLL), multiple myeloma (MM), and lymphoma (132134). Phase I and phase II clinical trials have tested the efficacy and safety of IL-21 administration in limiting malignant melanoma (135-138). These studies provide evidence for the use of IL-21 as a safe and effective immunotherapeutic agent in a broad range of diseases. Because of IL-21's profound effects in controlling IgE production, supplementation of IL-21 may be useful to rebalance the elevated IgE level in asthma (93). It is possible that IL-21 may have multiple roles in asthma, wherein it may sustain germinal center reaction while limiting Ig classswitching toward IgE. This dichotomy in the effects of IL-21 in asthma may be due to the timing and location at which IL21 is preferentially accumulated. Nevertheless, it is worthwhile to point out that IL-21 administration in other allergic mouse models, including skin allergy, allergic rhinitis, and anaphylaxis, impressively reduces allergen-specific IgE production (111-113). Again, these points of evidence provide confidence for the development and assessment of IL-21-based immunotherapy in allergic asthma.

On the other hand, amelioration of disease symptoms and improved health were observed after delivery of IL-21 neutralizing antibodies or IL-21R blockade in mice in multiple autoimmune and inflammatory disease models, including SLE (139), arthritis (140), graft-vs.-host disease (GVHD) (141, 142), and Crohn's Disease (143). Although it is still not very clear why IL-21 and IL-21R signaling play different roles in asthma, it will be very exciting to see more studies provide definitive evidence on IL-21's immunomodulating functions in regulating $\mathrm{T}_{\mathrm{FH}}$ cells, IgE production, and germinal center response in asthma.

\section{CONCLUSION}

In our review of the research using animal models and human patient samples, $\mathrm{T}_{\mathrm{FH}}$ cell and its signature cytokine IL-21 were evidenced to be largely involved in asthma. In particular, specialized subsets of $\mathrm{T}_{\mathrm{FH}}$ cells, such as $\mathrm{T}_{\mathrm{FH}} 2$ cells, $\mathrm{T}_{\mathrm{FH}} 13$ cells, and $\mathrm{T}_{\mathrm{FR}}$ cells closely regulate IgE production in asthma. Future 
studies using single-cell technology can help us better understand this heterogeneity of the $\mathrm{T}_{\mathrm{FH}}$ cell population in asthma patients and healthy cohorts. Future studies are also required to elucidate the connection between IL-21 and different subsets of $\mathrm{T}_{\mathrm{FH}}$ cells as well as $\mathrm{T}_{\mathrm{FR}}$ cells, and to determine how can we use this follicular regulatory network to control asthma disease. It also remains to be seen how $\mathrm{T}_{\mathrm{FH}}, \mathrm{T}_{\mathrm{FR}}$ cells and IL-21 are used to better classify the asthma patients, which may help clinicians design personalized and precise medicine for different individuals with asthma.

\section{AUTHOR CONTRIBUTIONS}

$\mathrm{PZ}, \mathrm{FG}$, and TZ wrote the manuscript. $\mathrm{PZ}$ revised the manuscript and led the submission.

\section{REFERENCES}

1. Papi A, Brightling C, Pedersen SE, Reddel HK. Asthma. Lancet. (2018) 391:783-800. doi: 10.1016/S0140-6736(17)33311-1

2. Suissa S, Ernst P, Benayoun S, Baltzan M, Cai B. Low-dose inhaled corticosteroids and the prevention of death from asthma. $N$ Engl J Med. (2000) 343:332-6. doi: 10.1056/NEJM200008033430504

3. Rowe BH, Spooner C, Ducharme FM, Bretzlaff JA, Bota GW. Early emergency department treatment of acute asthma with systemic corticosteroids. Cochrane Database Syst Rev. (2001) 1:CD002178. doi: 10.1002/14651858.CD002178

4. Hansbro PM, Kim RY, Starkey MR, Donovan C, Dua K, Mayall JR, et al. Mechanisms and treatments for severe, steroid-resistant allergic airway disease and asthma. Immunol Rev. (2017) 278:41-62. doi: 10.1111/imr.12543

5. Volmer T, Effenberger T, Trautner C, Buhl R. Consequences of long-term oral corticosteroid therapy and its side-effects in severe asthma in adults: a focused review of the impact data in the literature. Eur Respir J. (2018) 52:1800703. doi: 10.1183/13993003.00703-2018

6. Pavord ID, Beasley R, Agusti A, Anderson GP, Bel E, Brusselle G, et al. After asthma: redefining airways diseases. Lancet. (2018) 391:350-400. doi: 10.1016/S0140-6736(17)30879-6

7. Muehling LM, Lawrence MG, Woodfolk JA. Pathogenic CD4(+) T cells in patients with asthma. J Allergy Clin Immunol. (2017) 140:1523-40. doi: 10.1016/j.jaci.2017.02.025

8. Robinson DS, Hamid Q, Ying S, Tsicopoulos A, Barkans J, Bentley $\mathrm{AM}$, et al. Predominant TH2-like bronchoalveolar T-lymphocyte population in atopic asthma. $N$ Engl J Med. (1992) 326:298-304. doi: 10.1056/NEJM199201303260504

9. Lambrecht BN, Hammad H. The immunology of asthma. Nat Immunol. (2014) 16:45-56. doi: 10.1038/ni.3049

10. Kubo M. Innate and adaptive type 2 immunity in lung allergic inflammation. Immunol Rev. (2017) 278:162-72. doi: 10.1111/imr.12557

11. Ballesteros-Tato A, Randall TD, Lund FE, Spolski R, Leonard WJ, Leon B. $\mathrm{T}$ follicular helper cell plasticity shapes pathogenic $\mathrm{T}$ helper 2 cellmediated immunity to inhaled house dust mite. Immunity. (2016) 44:259-73. doi: 10.1016/j.immuni.2015.11.017

12. Coquet JM, Schuijs MJ, Smyth MJ, Deswarte K, Beyaert R, Braun H, et al. Interleukin-21-producing CD4(+) T cells promote type 2 immunity to house dust mites. Immunity. (2015) 43:318-30. doi: 10.1016/j.immuni.2015.07.015

13. Kobayashi T, Iijima K, Dent AL, Kita H. Follicular helper $\mathrm{T}$ cells mediate IgE antibody response to airborne allergens. J Allergy Clin Immunol. (2017) 139:300-13.e7. doi: 10.1016/j.jaci.2016.04.021

14. Noble A, Zhao J. Follicular helper T cells are responsible for IgE responses to Der p 1 following house dust mite sensitization in mice. Clin Exp Allergy. (2016) 46:1075-82. doi: 10.1111/cea.12750

15. Kubo M. T follicular helper and TH2 cells in allergic responses. Allergol Int. (2017) 66:377-81. doi: 10.1016/j.alit.2017.04.006

\section{FUNDING}

This work was supported by Six Talent Peaks Project in Jiangsu Province (2017-WSN-186) and Jiangsu Province 333 Project (BRA2019152) to FG, National Natural Science Foundation of China (81600692) to TZ and (81970759) to TZ and PZ, and Youth Science Funds of Shandong Academy of Sciences (2018QN003) to TZ.

\section{ACKNOWLEDGMENTS}

We thank Dr. Di Yu for reading the manuscript and providing constructive suggestions. The author apologizes to investigators whose contributions were not cited more extensively because of space limitations.

16. Breitfeld D, Ohl L, Kremmer E, Ellwart J, Sallusto F, Lipp M, et al. Follicular $\mathrm{B}$ helper T cells express CXC chemokine receptor 5, localize to B cell follicles, and support immunoglobulin production. J Exp Med. (2000) 192:1545-52. doi: 10.1084/jem.192.11.1545

17. Campbell DJ, Kim CH, Butcher EC. Separable effector T cell populations specialized for B cell help or tissue inflammation. Nat Immunol. (2001) 2:876-81. doi: 10.1038/ni0901-876

18. Kim CH, Rott LS, Clark-Lewis I, Campbell DJ, Wu L, Butcher EC. Subspecialization of CXCR5+ T cells: B helper activity is focused in a germinal center-localized subset of CXCR5+ T cells. J Exp Med. (2001) 193:1373-81. doi: 10.1084/jem.193.12.1373

19. Schaerli P, Willimann K, Lang AB, Lipp M, Loetscher $P$, Moser B. CXC chemokine receptor 5 expression defines follicular homing $\mathrm{T}$ cells with B cell helper function. J Exp Med. (2000) 192:1553-62. doi: 10.1084/jem.192.11.1553

20. Johnston RJ, Poholek AC, DiToro D, Yusuf I, Eto D, Barnett B, et al. Bcl6 and Blimp-1 are reciprocal and antagonistic regulators of $\mathrm{T}$ follicular helper cell differentiation. Science. (2009) 325:1006-10. doi: 10.1126/science.1175870

21. Nurieva RI, Chung Y, Martinez GJ, Yang XO, Tanaka S, Matskevitch TD, et al. Bcl6 mediates the development of T follicular helper cells. Science. (2009) 325:1001-5. doi: 10.1126/science.1176676

22. Yu D, Rao S, Tsai LM, Lee SK, He Y, Sutcliffe EL, et al. The transcriptional repressor Bcl-6 directs $\mathrm{T}$ follicular helper cell lineage commitment. Immunity. (2009) 31:457-68. doi: 10.1016/j.immuni.2009.07.002

23. Vinuesa CG, Linterman MA, Yu D, MacLennan IC. Follicular Helper T Cells. Annu Rev Immunol. (2016) 34:335-68. doi: 10.1146/annurev-immunol-041015-055605

24. Crotty S. T follicular helper cell biology: a decade of discovery and diseases. Immunity. (2019) 50:1132-48. doi: 10.1016/j.immuni.2019. 04.011

25. Vogelzang A, McGuire HM, Yu D, Sprent J, Mackay CR, King C. A fundamental role for interleukin-21 in the generation of $\mathrm{T}$ follicular helper cells. Immunity. (2008) 29:127-37. doi: 10.1016/j.immuni.2008.06.001

26. Chtanova T, Newton R, Liu SM, Weininger L, Young TR, Silva DG, et al. Identification of $\mathrm{T}$ cell-restricted genes, and signatures for different $\mathrm{T}$ cell responses, using a comprehensive collection of microarray datasets. $J$ Immunol. (2005) 175:7837-47. doi: 10.4049/jimmunol.175.12.7837

27. Choi YS, Kageyama R, Eto D, Escobar TC, Johnston RJ, Monticelli L, et al. ICOS receptor instructs $\mathrm{T}$ follicular helper cell versus effector cell differentiation via induction of the transcriptional repressor Bcl6. Immunity. (2011) 34:932-46. doi: 10.1016/j.immuni.2011.03.023

28. Li J, Lu E, Yi T, Cyster JG. EBI2 augments Tfh cell fate by promoting interaction with IL-2-quenching dendritic cells. Nature. (2016) 533:110-4. doi: 10.1038/nature17947

29. Shi J, Hou S, Fang Q, Liu X, Liu X, Qi H. PD-1 controls follicular $\mathrm{T}$ helper cell positioning and function. Immunity. (2018) 49:264-74.e4. doi: 10.1016/j.immuni.2018.06.012 
30. Xu H, Li X, Liu D, Li J, Zhang X, Chen X, et al. Follicular T-helper cell recruitment governed by bystander B cells and ICOS-driven motility. Nature. (2013) 496:523-7. doi: 10.1038/nature12058

31. Weber JP, Fuhrmann F, Feist RK, Lahmann A, Al Baz MS, Gentz $\mathrm{LJ}$, et al. ICOS maintains the $\mathrm{T}$ follicular helper cell phenotype by down-regulating Kruppel-like factor 2. J Exp Med. (2015) 212:217-33. doi: 10.1084 /jem.20141432

32. Hatzi K, Nance JP, Kroenke MA, Bothwell M, Haddad EK, Melnick A, et al. BCL6 orchestrates Tfh cell differentiation via multiple distinct mechanisms. J Exp Med. (2015) 212:539-53. doi: 10.1084/jem.20141380

33. Crotty S. T follicular helper cell differentiation, function, and roles in disease. Immunity. (2014) 41:529-42. doi: 10.1016/j.immuni.2014.10.004

34. Sweet RA, Lee SK, Vinuesa CG. Developing connections amongst key cytokines and dysregulated germinal centers in autoimmunity. Curr Opin Immunol. (2012) 24:658-64. doi: 10.1016/j.coi.2012.10.003

35. Schmitt N, Morita R, Bourdery L, Bentebibel SE, Zurawski SM, Banchereau J, et al. Human dendritic cells induce the differentiation of interleukin-21producing $\mathrm{T}$ follicular helper-like cells through interleukin-12. Immunity. (2009) 31:158-69. doi: 10.1016/j.immuni.2009.04.016

36. Cucak H, Yrlid U, Reizis B, Kalinke U, Johansson-Lindbom B. Type I interferon signaling in dendritic cells stimulates the development of lymph-node-resident T follicular helper cells. Immunity. (2009) 31:491-501. doi: 10.1016/j.immuni.2009.07.005

37. Papillion A, Powell MD, Chisolm DA, Bachus H, Fuller MJ, Weinmann $\mathrm{AS}$, et al. Inhibition of IL-2 responsiveness by IL-6 is required for the generation of GC-TFH cells. Sci Immunol. (2019) 4:eaaw7636. doi: 10.1126/sciimmunol.aaw7636

38. Zhou P, Liang K, Yu D. Germinal center TFH cells: T(w)o be or not $\mathrm{t}(\mathrm{w}) \mathrm{o}$ be, IL-6 is the answer. Sci Immunol. (2019) 4:aay7668. doi: 10.1126/sciimmunol.aay7668

39. Schmitt N, Liu Y, Bentebibel SE, Munagala I, Bourdery L, Venuprasad K, et al. The cytokine TGF- $\beta$ co-opts signaling via STAT3-STAT4 to promote the differentiation of human TFH cells. Nat Immunol. (2014) 15:856-65. doi: $10.1038 /$ ni.2947

40. Ballesteros-Tato A, Leon B, Graf BA, Moquin A, Adams PS, Lund $\mathrm{FE}$, et al. Interleukin-2 inhibits germinal center formation by limiting $\mathrm{T}$ follicular helper cell differentiation. Immunity. (2012) 36:847-56. doi: 10.1016/j.immuni.2012.02.012

41. He J, Zhang X, Wei Y, Sun X, Chen Y, Deng J, et al. Low-dose interleukin-2 treatment selectively modulates CD4(+) $\mathrm{T}$ cell subsets in patients with systemic lupus erythematosus. Nat Med. (2016) 22:991-3. doi: $10.1038 / \mathrm{nm} .4148$

42. Reinhardt RL, Liang HE, Locksley RM. Cytokine-secreting follicular T cells shape the antibody repertoire. Nat Immunol. (2009) 10:385-93. doi: 10.1038/ni.1715

43. Zaretsky I, Atrakchi O, Mazor RD, Stoler-Barak L, Biram A, Feigelson SW, et al. ICAMs support B cell interactions with $\mathrm{T}$ follicular helper cells and promote clonal selection. J Exp Med. (2017) 214:3435-48. doi: $10.1084 /$ jem.20171129

44. Hirota K, Turner JE, Villa M, Duarte JH, Demengeot J, Steinmetz OM, et al. Plasticity of Th17 cells in Peyer's patches is responsible for the induction of T cell-dependent IgA responses. Nat Immunol. (2013) 14:372-9. doi: $10.1038 /$ ni.2552

45. MacLeod MK, David A, McKee AS, Crawford F, Kappler JW, Marrack P. Memory CD4 T cells that express CXCR5 provide accelerated help to B cells. J Immunol. (2011) 186:2889-96. doi: 10.4049/jimmunol.1002955

46. Koutsakos M, Wheatley AK, Loh L, Clemens EB, Sant S, Nussing S, et al. Circulating TFH cells, serological memory, and tissue compartmentalization shape human influenza-specific B cell immunity. Sci Transl Med. (2018) 10:eaan8405. doi: 10.1126/scitranslmed.aan8405

47. Luthje K, Kallies A, Shimohakamada Y, Belz GT, Light A, Tarlinton DM, et al. The development and fate of follicular helper $\mathrm{T}$ cells defined by an IL-21 reporter mouse. Nat Immunol. (2012) 13:491-8. doi: 10.1038/ni.2261

48. Barr T, Gray D. TFH memory: more or less TFH? Euro J Immunol. (2012) 42:1977-80. doi: 10.1002/eji.201242755

49. Weinstein JS, Herman EI, Lainez B, Licona-Limon P, Esplugues E, Flavell $\mathrm{R}$, et al. TFH cells progressively differentiate to regulate the germinal center response. Nat Immunol. (2016) 17:1197-205. doi: 10.1038/ni.3554
50. Morita R, Schmitt N, Bentebibel SE, Ranganathan R, Bourdery L, Zurawski G, et al. Human blood CXCR5(+)CD4(+) $\mathrm{T}$ cells are counterparts of $\mathrm{T}$ follicular cells and contain specific subsets that differentially support antibody secretion. Immunity. (2011) 34:108-21. doi: 10.1016/j.immuni.2010.12.012

51. Rao DA, Gurish MF, Marshall JL, Slowikowski K, Fonseka CY, Liu Y, et al. Pathologically expanded peripheral $\mathrm{T}$ helper cell subset drives $\mathrm{B}$ cells in rheumatoid arthritis. Nature. (2017) 542:110-4. doi: 10.1038/nature20810

52. Bocharnikov AV, Keegan J, Wacleche VS, Cao Y, Fonseka CY, Wang G, et al. PD-1hi CXCR5- T peripheral helper cells promote B cells responses in lupus via MAF and IL-21. JCI Insight. (2019). doi: 10.1172/jci.insight.130062

53. Caielli S, Veiga DT, Balasubramanian P, Athale S, Domic B, Murat E, et al. A CD4(+) T cell population expanded in lupus blood provides B cell help through interleukin-10 and succinate. Nat Med. (2019) 25:75-81. doi: 10.1038/s41591-018-0254-9

54. He J, Tsai LM, Leong YA, Hu X, Ma CS, Chevalier N, et al. Circulating precursor CCR7(lo)PD-1(hi) CXCR5(+) CD4(+) $\mathrm{T}$ cells indicate Tfh cell activity and promote antibody responses upon antigen reexposure. Immunity. (2013) 39:770-81. doi: 10.1016/j.immuni.2013.09.007

55. Locci M, Havenar-Daughton C, Landais E, Wu J, Kroenke MA, Arlehamn CL, et al. Human circulating PD-1+CXCR3-CXCR5+ memory Tfh cells are highly functional and correlate with broadly neutralizing HIV antibody responses. Immunity. (2013) 39:758-69. doi: 10.1016/j.immuni.2013.08.031

56. Schmitt N, Bentebibel SE, Ueno $H$. Phenotype and functions of memory Tfh cells in human blood. Trends Immunol. (2014) 35:436-42. doi: 10.1016/j.it.2014.06.002

57. Ueno H, Banchereau J, Vinuesa CG. Pathophysiology of $\mathrm{T}$ follicular helper cells in humans and mice. Nat Immunol. (2015) 16:142-52. doi: 10.1038/ni.3054

58. Gowthaman U, Chen JS, Zhang B, Flynn WF, Lu Y, Song W, et al. Identification of a $\mathrm{T}$ follicular helper cell subset that drives anaphylactic IgE. Science. (2019) 365:eaaw6433. doi: 10.1126/science.aaw6433

59. Dolence JJ, Kobayashi T, Iijima K, Krempski J, Drake LY, Dent AL, et al. Airway exposure initiates peanut allergy by involving the IL-1 pathway and T follicular helper cells in mice. J Allergy Clin Immunol. (2018) 142:1144-58.e8. doi: 10.1016/j.jaci.2017.11.020

60. Van V, Beier KC, Pietzke LJ, Al Baz MS, Feist RK, Gurka S, et al. Local T/B cooperation in inflamed tissues is supported by $\mathrm{T}$ follicular helper-like cells. Nat Commun. (2016) 7:10875. doi: 10.1038/ncomms10875

61. Van DV, Bauer L, Kroczek RA, Hutloff A. ICOS costimulation differentially affects T cells in secondary lymphoid organs and inflamed tissues. Am J Resp Cell Mol. (2018) 59:437-47. doi: 10.1165/rcmb.2017-0309OC

62. Clement RL, Daccache J, Mohammed MT, Diallo A, Blazar BR, Kuchroo VK, et al. Follicular regulatory $\mathrm{T}$ cells control humoral and allergic immunity by restraining early B cell responses. Nat Immunol. (2019) 20:1360-71. doi: 10.1038/s41590-019-0472-4

63. Lal G, Kulkarni N, Nakayama Y, Singh AK, Sethi A, Burrell BE, et al. IL-10 from marginal zone precursor B cells controls the differentiation of Th17, Tfh and Tfr cells in transplantation tolerance. Immunol Lett. (2016) 170:52-63. doi: 10.1016/j.imlet.2016.01.002

64. Jandl C, Liu SM, Canete PF, Warren J, Hughes WE, Vogelzang A, et al. IL-21 restricts $\mathrm{T}$ follicular regulatory $\mathrm{T}$ cell proliferation through $\mathrm{Bcl}-6$ mediated inhibition of responsiveness to IL-2. Nat Commun. (2017) 8:14647. doi: $10.1038 /$ ncomms 14647

65. Wing JB, Ise W, Kurosaki T, Sakaguchi S. Regulatory $\mathrm{T}$ cells control antigen-specific expansion of Th cell number and humoral immune responses via the coreceptor CTLA-4. Immunity. (2014) 41:1013-25. doi: 10.1016/j.immuni.2014.12.006

66. Gong F, Qian C, Zhu H, Zhu J, Pan Y, Dong Q, et al. Circulating follicular Thelper cell subset distribution in patients with asthma. Allergy Asthma Proc. (2016) 37:154-61. doi: 10.2500/aap.2016.37.3982

67. Zhang D, Wu Y, Sun G. miR-192 suppresses $\mathrm{T}$ follicular helper cell differentiation by targeting CXCR5 in childhood asthma. Scand J Clin Lab Invest. (2018) 78:236-42. doi: 10.1080/00365513.2018.1440628

68. Yao Y, Chen CL, Wang N, Wang ZC, Ma J, Zhu RF, et al. Correlation of allergen-specific $\mathrm{T}$ follicular helper cell counts with specific IgE levels and efficacy of allergen immunotherapy. J Allergy Clin Immunol. (2018) 142:321-4.e10. doi: 10.1016/j.jaci.2018.03.008 
69. Schulten V, Tripple V, Seumois G, Qian Y, Scheuermann RH, Fu $Z$, et al. Allergen-specific immunotherapy modulates the balance of circulating Tfh and Tfr cells. J Allergy Clin Immunol. (2018) 141:775-7.e6. doi: 10.1016/j.jaci.2017.04.032

70. Yao Y, Wang ZC, Wang N, Zhou PC, Chen CL, Song J, et al. Allergen immunotherapy improves defective follicular regulatory $\mathrm{T}$ cells in patients with allergic rhinitis. J Allergy Clin Immunol. (2019) 144:118-28. doi: 10.1016/j.jaci.2019.02.008.

71. Hawrylowicz CM. Regulatory $\mathrm{T}$ cells and IL-10 in allergic inflammation. J Exp Med. (2005) 202:1459-63. doi: 10.1084/jem.20 052211

72. Hawrylowicz CM, O'Garra A. Potential role of interleukin-10-secreting regulatory T cells in allergy and asthma. Nat Rev Immunol. (2005) 5:271-83. doi: $10.1038 /$ nri1589

73. Kearley J, Barker JE, Robinson DS, Lloyd CM. Resolution of airway inflammation and hyperreactivity after in vivo transfer of CD4+CD25+ regulatory T cells is interleukin 10 dependent. J Exp Med. (2005) 202:153947. doi: 10.1084/jem.20051166

74. Nials AT, Uddin S. Mouse models of allergic asthma: acute and chronic allergen challenge. Dis Model Mech. (2008) 1:213-20. doi: $10.1242 / \mathrm{dmm} .000323$

75. Chevalier N, Jarrossay D, Ho E, Avery DT, Ma CS, Yu D, et al. CXCR5 expressing human central memory CD4T cells and their relevance for humoral immune responses. J Immunol. (2011) 186:5556-68. doi: 10.4049/jimmunol.1002828

76. Pepper M, Pagan AJ, Igyarto BZ, Taylor JJ, Jenkins MK. Opposing signals from the Bcl6 transcription factor and the interleukin-2 receptor generate T helper 1 central and effector memory cells. Immunity. (2011) 35:583-95. doi: 10.1016/j.immuni.2011.09.009

77. Gong F, Zhu HY, Zhu J, Dong QJ, Huang X, Jiang DJ. Circulating CXCR5(+)CD4(+) $\mathrm{T}$ cells participate in the IgE accumulation in allergic asthma. Immunol Lett. (2018) 197:9-14. doi: 10.1016/j.imlet.2018.03.001

78. Yamamoto M, Singh A, Ruan J, Gauvreau GM, O’Byrne PM, Carlsten CR, et al. Decreased miR-192 expression in peripheral blood of asthmatic individuals undergoing an allergen inhalation challenge. BMC Genomics. (2012) 13:655. doi: 10.1186/1471-2164-13-655

79. Ozaki K, Kikly K, Michalovich D, Young PR, Leonard WJ. Cloning of a type I cytokine receptor most related to the IL-2 receptor beta chain. Proc Natl Acad Sci USA. (2000) 97:11439-44. doi: 10.1073/pnas.200360997

80. Parrish-Novak J, Dillon SR, Nelson A, Hammond A, Sprecher C, Gross $\mathrm{JA}$, et al. Interleukin 21 and its receptor are involved in NK cell expansion and regulation of lymphocyte function. Nature. (2000) 408:57-63. doi: 10.1038/35040504

81. Tangye SG. Advances in IL-21 biology - enhancing our understanding of human disease. Curr Opin Immunol. (2015) 34:107-15. doi: 10.1016/j.coi.2015.02.010

82. Spolski R, Leonard WJ. Interleukin-21: a double-edged sword with therapeutic potential. Nat Rev Drug Disc. (2014) 13:379-95. doi: $10.1038 / \operatorname{nrd} 4296$

83. Spolski R, Leonard WJ. Interleukin-21: basic biology and implications for cancer and autoimmunity. Ann Rev Immunol. (2008) 26:57-79. doi: 10.1146/annurev.immunol.26.021607.0 90316

84. Roda JM, Parihar R, Lehman A, Mani A, Tridandapani S, Carson WE. Interleukin-21 enhances NK cell activation in response to antibodycoated targets. J Immunol. (2006) 177:120-9. doi: 10.4049/jimmunol.177. 1.120

85. Smyth MJ, Wallace ME, Nutt SL, Yagita H, Godfrey DI, Hayakawa Y. Sequential activation of NKT cells and NK cells provides effective innate immunotherapy of cancer (vol. 201, pg 1973, 2005). J Exp Med. (2005) 202:569. doi: $10.1084 /$ jem.20042280

86. Frohlich A, Kisielow J, Schmitz I, Freigang S, Shamshiev AT, Weber J, et al. IL-21R on T cells is critical for sustained functionality and control of chronic viral infection. Science. (2009) 324:1576-80. doi: 10.1126/science.11 72815

87. Elsaesser H, Sauer K, Brooks DG. IL-21 is required to control chronic viral infection. Science. (2009) 324:1569-72. doi: 10.1126/science.1174182
88. Wei L, Laurence A, Elias KM, O'Shea JJ. IL-21 is produced by Th17 cells and drives IL-17 production in a STAT3-dependent manner. J Biol Chem. (2007) 282:34605-10. doi: 10.1074/jbc.M705100200

89. Korn T, Bettelli E, Gao W, Awasthi A, Jager A, Strom TB, et al. IL-21 initiates an alternative pathway to induce proinflammatory $\mathrm{T}(\mathrm{H}) 17$ cells. Nature. (2007) 448:484-7. doi: 10.1038/nature05970

90. Bauquet AT, Jin HL, Paterson AM, Mitsdoerffer M, Ho IC, Sharpe AH, et al. The costimulatory molecule ICOS regulates the expression of c-Maf and IL-21 in the development of follicular T helper cells and T-H-17 cells. Nat Immunol. (2009) 10:167-75. doi: 10.1038/ni.1690

91. Ozaki K, Spolski R, Ettinger R, Kim HP, Wang G, Qi CF, et al. Regulation of B cell differentiation and plasma cell generation by IL-21, a novel inducer of blimp-1 and bcl-61. J Immunol. (2004) 173:5361-71. doi: 10.4049/jimmunol.173.9.5361

92. Gharibi T, Majidi J, Kazemi T, Dehghanzadeh R, Motallebnezhad M, Babaloo Z. Biological effects of IL-21 on different immune cells and its role in autoimmune diseases. Immunobiology. (2016) 221:357-67. doi: 10.1016/j.imbio.2015.09.021

93. Ozaki K, Spolski R, Feng CG, Qi CF, Cheng J, Sher A, et al. A critical role for IL-21 in regulating immunoglobulin production. Science. (2002) 298:1630-4. doi: 10.1126/science.1077002

94. Asao H, Okuyama C, Kumaki S, Ishii N, Tsuchiya S, Foster D, et al. Cutting edge: the common gamma-chain is an indispensable subunit of the IL-21 receptor complex. J Immunol. (2001) 167:1-5. doi: 10.4049/jimmunol.167.1.1

95. Zhou L, Ivanov, II, Spolski R, Min R, Shenderov K, Egawa T, et al. IL-6 programs $\mathrm{T}(\mathrm{H})-17$ cell differentiation by promoting sequential engagement of the IL-21 and IL-23 pathways. Nat Immunol. (2007) 8:967-74. doi: $10.1038 /$ nil 1488

96. Ivanov, II, Zhou L, Littman DR. Transcriptional regulation of Th17 cell differentiation. Semin Immunol. (2007) 19:409-17. doi: 10.1016/j.smim.2007.10.011

97. Nurieva RI, Chung Y, Hwang D, Yang XO, Kang HS, Ma L, et al. Generation of $\mathrm{T}$ follicular helper cells is mediated by interleukin-21 but independent of T helper 1, 2, or 17 cell lineages. Immunity. (2008) 29:138-49. doi: 10.1016/j.immuni.2008.05.009

98. Eto D, Lao C, DiToro D, Barnett B, Escobar TC, Kageyama R, et al. IL-21 and IL-6 are critical for different aspects of B cell immunity and redundantly induce optimal follicular helper CD4 T cell (Tfh) differentiation. PLoS ONE. (2011) 6:e17739. doi: 10.1371/journal.pone.0 017739

99. Gao X, Wang H, Chen Z, Zhou P, Yu D. An optimised method to differentiate mouse follicular helper $\mathrm{T}$ cells in vitro. Cell Mol Immunol. (2019). doi: 10.1038/s41423-019-0329-7. [Epub ahead of print].

100. Kwon H, Thierry-Mieg D, Thierry-Mieg J, Kim HP, Oh J, Tunyaplin C, et al. Analysis of interleukin-21-induced Prdm1 gene regulation reveals functional cooperation of STAT3 and IRF4 transcription factors. Immunity. (2009) 31:941-52. doi: 10.1016/j.immuni.2009.10.008

101. Zotos D, Coquet JM, Zhang Y, Light A, D'Costa K, Kallies A, et al. IL-21 regulates germinal center $B$ cell differentiation and proliferation through a B cell-intrinsic mechanism. J Exp Med. (2010) 207:365-78. doi: 10.1084/jem.20091777

102. Linterman MA, Beaton L, Yu D, Ramiscal RR, Srivastava M, Hogan JJ, et al. IL-21 acts directly on B cells to regulate Bcl-6 expression and germinal center responses. J Exp Med. (2010) 207:353-63. doi: 10.1084/jem.200 91738

103. Jin HL, Carrio R, Yu AX, Malek TR. Distinct activation signals determine whether IL-21 induces B cell costimulation, growth arrest, or bim-dependent apoptosis. J Immunol. (2004) 173:657-65. doi: 10.4049/jimmunol.17 3.1.657

104. Gowda A, Roda J, Hussain SRA, Ramanunni A, Joshi T, Schmidt S, et al. IL-21 mediates apoptosis through up-regulation of the BH3 family member BIM and enhances both direct and antibody-dependent cellular cytotoxicity in primary chronic lymphocytic leukemia cells in vitro. Blood. (2008) 111:472330. doi: 10.1182/blood-2007-07-099531

105. Lajoie S, Lewkowich I, Herman NS, Sproles A, Pesce JT, Wynn TA, et al. IL-21 receptor signalling partially mediates Th2-mediated allergic 
airway responses. Clin Exp Allergy. (2014) 44:976-85. doi: 10.1111/cea. 12341

106. He Y, Lou X, Jin Z, Yu L, Deng L, Wan H. Mahuang decoction mitigates airway inflammation and regulates IL-21/STAT3 signaling pathway in rat asthma model. J Ethnopharmacol. (2018) 224:373-80. doi: 10.1016/j.jep.2018.06.011

107. Cheng S, Chen H, Wang A, Bunjhoo H, Cao Y, Xie J, et al. Exclusion of IL21 in the pathogenesis of OVA-induced asthma in mice. Int J Clin Exp Med. (2014) 7:3202-8.

108. Chen H, Cheng S, Wang A, Bunjhoo H, Cao Y, Xie J, et al. IL-21 does not involve in OVA-induced airway remodeling and chronic airway inflammation. Int J Clin Exp Med. (2015) 8:10640-5.

109. Suto A, Nakajima H, Hirose K, Suzuki K, Kagami S, Seto Y, et al. Interleukin 21 prevents antigen-induced IgE production by inhibiting germ line C(epsilon) transcription of IL-4-stimulated B cells. Blood. (2002) 100:4565-73. doi: 10.1182/blood-2002-04-1115

110. Harada M, Magara-Koyanagi K, Watarai H, Nagata Y, Ishii Y, Kojo S, et al. IL-21-induced Bepsilon cell apoptosis mediated by natural killer T cells suppresses IgE responses. J Exp Med. (2006) 203:2929-37. doi: 10.1084/jem.20062206

111. Hiromura $Y$, Kishida $T$, Nakano $H$, Hama $T$, Imanishi $J$, Hisa $Y$, et al. IL-21 administration into the nostril alleviates murine allergic rhinitis. J Immunol. (2007) 179:7157-65. doi: 10.4049/jimmunol.179. 10.7157

112. Kishida T, Hiromura Y, Shin-Ya M, Asada H, Kuriyama H, Sugai M, et al. IL-21 induces inhibitor of differentiation 2 and leads to complete abrogation of anaphylaxis in mice. J Immunol. (2007) 179:8554-61. doi: 10.4049/jimmunol.179.12.8554

113. Tamagawa-Mineoka R, Kishida T, Mazda O, Katoh N. IL-21 reduces immediate hypersensitivity reactions in mouse skin by suppressing mast cell activation or IgE production. J Invest Dermatol. (2011) 131:1513-20. doi: $10.1038 /$ jid. 2011.73

114. Frohlich A, Marsland BJ, Sonderegger I, Kurrer M, Hodge MR, Harris $\mathrm{NL}$, et al. IL-21 receptor signaling is integral to the development of Th2 effector responses in vivo. Blood. (2007) 109:2023-31. doi: 10.1182/blood-2006-05-021600

115. Lin PY, Jen HY, Chiang BL, Sheu F, Chuang YH. Interleukin-21 suppresses the differentiation and functions of $\mathrm{T}$ helper 2 cells. Immunology. (2015) 144:668-76. doi: 10.1111/imm.12419

116. Wu J, Zhang S, Qin T, Jiang J, Liu Q, Zhang L, et al. IL-21 alleviates allergic asthma in DOCK8-knockout mice. Biochem Biophys Res Commun. (2018) 501:92-9. doi: 10.1016/j.bbrc.2018. 04.179

117. Gong F, Su Q, Jiang D, Chen J, Pan Y, Huang X. High frequency of circulating follicular helper $\mathrm{T}$ cells in patients with bronchial asthma. Clin Lab. (2014) 60:963-8. doi: 10.7754/Clin.Lab.2013.1 30427

118. Chatterjee R, Batra J, Ghosh B. A common exonic variant of interleukin21 confers susceptibility to atopic asthma. Int Arch Allergy Immunol. (2009) 148:137-46. doi: 10.1159/000155744

119. Wing JB, Sakaguchi S. Foxp3(+) T(reg) cells in humoral immunity. Int Immunol. (2014) 26:61-9. doi: 10.1093/intimm/dxt060

120. Tai Y, Sakamoto K, Takano A, Haga K, Harada Y. Dysregulation of humoral immunity in Foxp3 conditional-knockout mice. Biochem Biophys Res Commun. (2019) 513:787-93. doi: 10.1016/j.bbrc.2019. 04.090

121. Leonardo SM, De Santis JL, Gehrand A, Malherbe LP, Gauld SB. Expansion of follicular helper $\mathrm{T}$ cells in the absence of Treg cells: implications for loss of B-cell anergy. Eur J Immunol. (2012) 42:2597-607. doi: 10.1002/eji.2012 42616

122. Chung Y, Tanaka S, Chu F, Nurieva RI, Martinez GJ, Rawal S, et al. Follicular regulatory $\mathrm{T}$ cells expressing Foxp3 and Bcl-6 suppress germinal center reactions. Nat Med. (2011) 17:983-8. doi: 10.1038/n $\mathrm{m} .2426$

123. Linterman MA, Pierson W, Lee SK, Kallies A, Kawamoto S, Rayner TF, et al. Foxp3+ follicular regulatory $\mathrm{T}$ cells control the germinal center response. Nat Med. (2011) 17:975-82. doi: 10.1038/nm.2425
124. Deng J, Wei Y, Fonseca VR, Graca L, Yu D. T follicular helper cells and T follicular regulatory cells in rheumatic diseases. Nat Rev Rheumatol. (2019) 15:475-90. doi: 10.1038/s41584-019-0254-2

125. Botta D, Fuller MJ, Marquez-Lago TT, Bachus H, Bradley JE, Weinmann AS, et al. Dynamic regulation of $\mathrm{T}$ follicular regulatory cell responses by interleukin 2 during influenza infection. Nat Immunol. (2017) 18:1249-60. doi: 10.1038/ni.3837

126. Canete PF, Sweet RA, Gonzalez-Figueroa P, Papa I, Ohkura N, Bolton H, et al. Regulatory roles of IL-10-producing human follicular $\mathrm{T}$ cells. J Exp Med. (2019) 216:1843-56. doi: 10.1084/jem.201 90493

127. Holgate ST, Polosa R. Treatment strategies for allergy and asthma. Nat Rev Immunol. (2008) 8:218-30. doi: 10.1038/nri2262

128. McDonald PW, Read KA, Baker CE, Anderson AE, Powell MD, Ballesteros-Tato A, et al. IL-7 signalling represses Bcl-6 and the TFH gene program. Nat Commun. (2016) 7:10285. doi: 10.1038/ncomm s10285

129. Ray JP, Marshall HD, Laidlaw BJ, Staron MM, Kaech SM, Craft J. Transcription factor STAT3 and type I interferons are corepressive insulators for differentiation of follicular helper and T helper 1 cells. Immunity. (2014) 40:367-77. doi: 10.1016/j.immuni.2014.02.005

130. Huber JP, Gonzales-van Horn SR, Roybal KT, Gill MA, Farrar JD. IFN-alpha suppresses GATA3 transcription from a distal exon and promotes H3K27 trimethylation of the CNS-1 enhancer in human Th2 cells. J Immunol. (2014) 192:5687-94. doi: 10.4049/jimmunol.1301908

131. Duerr CU, McCarthy CD, Mindt BC, Rubio M, Meli AP, Pothlichet J, et al. Type I interferon restricts type 2 immunopathology through the regulation of group 2 innate lymphoid cells. Nat Immunol. (2016) 17:65-75. doi: $10.1038 /$ ni. 3308

132. Bubier JA, Sproule TJ, Foreman O, Spolski R, Shaffer DJ, Morse HC 3rd, et al. A critical role for IL-21 receptor signaling in the pathogenesis of systemic lupus erythematosus in BXSB-Yaa mice. Proc Natl Acad Sci USA. (2009) 106:1518-23. doi: 10.1073/pnas.0807309106

133. Kotlarz D, Zietara N, Uzel G, Weidemann T, Braun CJ, Diestelhorst J, et al. Loss-of-function mutations in the IL-21 receptor gene cause a primary immunodeficiency syndrome. J Exp Med. (2013) 210:433-43. doi: $10.1084 /$ jem. 20111229

134. Ma J, Ma D, Ji C. The role of IL-21 in hematological malignancies. Cytokine. (2011) 56:133-9. doi: 10.1016/j.cyto.2011. 07.011

135. Rasmussen MA, Colding-Jorgensen M, Hansen LT, Bro R. Multivariate evaluation of pharmacological responses in early clinical trials - a study of rIL-21 in the treatment of patients with metastatic melanoma. Br J Clin Pharmacol. (2010) 69:379-90. doi: 10.1111/j.1365-2125.2009.03600.x

136. Thompson JA, Curti BD, Redman BG, Bhatia S, Weber JS, Agarwala SS, et al. Phase I study of recombinant interleukin-21 in patients with metastatic melanoma and renal cell carcinoma. J Clin Oncol. (2008) 26:20349. doi: 10.1200/JCO.2007.14.5193

137. Hashmi MH, Van Veldhuizen PJ. Interleukin-21: updated review of Phase I and II clinical trials in metastatic renal cell carcinoma, metastatic melanoma and relapsed/refractory indolent non-Hodgkin's lymphoma. Expert Opin Biol Ther. (2010) 10:807-17. doi: 10.1517/14712598.2010.480971

138. Davis ID, Brady B, Kefford RF, Millward M, Cebon J, Skrumsager $\mathrm{BK}$, et al. Clinical and biological efficacy of recombinant human interleukin-21 in patients with stage IV malignant melanoma without prior treatment: a phase IIa trial. Clin Cancer Res. (2009) 15:2123-9. doi: 10.1158/1078-0432.CCR-08-2663

139. Zhang M, Yu G, Chan B, Pearson JT, Rathanaswami P, Delaney J, et al. Interleukin-21 receptor blockade inhibits secondary humoral responses and halts the progression of preestablished disease in the (NZB x NZW)F1 systemic lupus erythematosus model. Arthritis Rheumatol. (2015) 67:272331. doi: 10.1002/art.39233

140. Roeleveld DM, Marijnissen RJ, Walgreen B, Helsen MM, van den Bersselaar L, van de Loo FA, et al. Higher efficacy of anti-IL-6/IL-21 combination therapy compared to monotherapy in the induction phase of Th17-driven experimental arthritis. PLoS ONE. (2017) 12:e0171757. doi: 10.1371/journal.pone.0171757 
141. Hippen KL, Bucher C, Schirm DK, Bearl AM, Brender T, Mink KA, et al. Blocking IL-21 signaling ameliorates xenogeneic GVHD induced by human lymphocytes. Blood. (2012) 119:619-28. doi: 10.1182/blood-2011-07-368027

142. Bucher C, Koch L, Vogtenhuber C, Goren E, Munger M, PanoskaltsisMortari A, et al. IL-21 blockade reduces graft-versus-host disease mortality by supporting inducible $\mathrm{T}$ regulatory cell generation. Blood. (2009) 114:5375-84. doi: 10.1182/blood-2009-05-221135

143. Holm TL, Tornehave D, Sondergaard H, Kvist PH, Sondergaard BC, Hansen L, et al. Evaluating IL-21 as a potential therapeutic target in Crohn's disease. Gastroenterol Res Pract. (2018) 2018:5962624. doi: 10.1155/2018/5962624
Conflict of Interest: The authors declare that the research was conducted in the absence of any commercial or financial relationships that could be construed as a potential conflict of interest.

Copyright (๑) 2019 Gong, Zheng and Zhou. This is an open-access article distributed under the terms of the Creative Commons Attribution License (CC BY). The use, distribution or reproduction in other forums is permitted, provided the original author(s) and the copyright owner(s) are credited and that the original publication in this journal is cited, in accordance with accepted academic practice. No use, distribution or reproduction is permitted which does not comply with these terms. 